\title{
Effects of extrusion of rice bran on performance and phosphorous bioavailability in broiler chickens
}

\author{
Ali Akbar Zare-Sheibani ${ }^{2 *}$, Masoud Arab², Mohammad Javad Zamiri ${ }^{2}$, Mohammad Reza Rezvani², \\ Mohammad Dadpasand ${ }^{2}$ and Farhad Ahmadi, ${ }^{1,2}$
}

\begin{abstract}
Background: Rice bran is a by-product of the rice-milling process, which remains largely underutilized; however, efficient processing treatments may improve its feeding value for chickens. This is of great economic and environmental importance, as this can lower the production costs, and offer an opportunity for valorization of a low-quality agricultural by-product, to a high-value feed source.

Methods: This experiment was conducted to study the effect of extruded rice bran on performance and phosphorous (P) bioavailability in broiler chickens. In a completely randomized design, 200 seven-day-old broilers (Cobb 500) were allotted to five treatments with five replicates per treatment and 8 chicks per replicate, and fed with their respective diet during the starter (8 to 21 days) and grower (22 to 42 days) periods. Diets were a basal corn-soybean based diet (T1), or diets containing $20 \%$ rice bran (T2), $30 \%$ rice bran (T3), $20 \%$ extruded rice bran (T4), or $30 \%$ extruded rice bran (T5).

Results: Birds feeding on T4 and T5 diets had a higher body weight gain and lower feed-to-gain ratio compared to those feeding on T2 and T3 diets $(p<0.05)$. Birds receiving diets containing extruded rice bran had higher total P availability and tibia ash content, as compared with those receiving diets containing un-extruded rice bran $(p<0.05)$. Relative weight of the pancreas was higher in birds receiving T2 and T3 diets.

Conclusions: The results confirmed the beneficial effect of extrusion treatment of rice bran on performance and $P$ availability in broilers. Up to $30 \%$ extruded rice bran may be included in the broiler diet without apparent adverse effects on the performance.
\end{abstract}

Keywords: Rice bran, Extrusion, P availability, Performance, Broiler chicken

\section{Background}

Rice bran, an important by-product of the rice milling industry, has the potential to be used as an alternative to grains in the poultry diet [1]. It contains $15-22 \%$ oil, $11-17 \%$ protein, $6-14 \%$ fiber, $10-15 \%$ moisture, and 8-17\% ash [2]; however, the presence of anti-nutritional factors such as phytic acid [3], trypsin inhibitor and hemagglutinin [4], high fiber content [5], and instability during storage [6] limit its use in poultry nutrition. Pancreatic hypertrophy [7, 8], depressed

\footnotetext{
*Correspondence: Akbarzare.1391@gmail.com

${ }^{2}$ Department of Animal Science, College of Agriculture, Shiraz University, 71441-65186 Shiraz, Iran

Full list of author information is available at the end of the article
}

intestinal amylase activity [8], and reduction in feed consumption [9] and growth [10] have been reported as the side effects of feeding raw rice bran to broilers.

Approximately $90 \%$ of $\mathrm{P}$ in rice bran is in the form of phytic acid and phytate chelated with other elements; phytate not only does reduce $\mathrm{P}$ availability, but also decreases the absorption of elements such as zinc, iron, calcium and magnesium [11]. In addition, it decreases protein digestibility and energy use through inhibition of the enzymes such as pepsin, trypsin and $\alpha$-amylase $[12,13]$. Rice bran also contains lipase and peroxide which are released during rice polishing and cause lipid oxidation $[2,14]$. Therefore, it is necessary to stabilize the rice bran by effective pretreatments to limit the 
undesirable reactions [2]. The extrusion cooking technology, a thermal/mechanical pretreatment applying heat treatment in the presence of moisture, is an effective processing method causing physico-chemical and nutritional modifications of the food constituents, such as permanently denaturing lipases [15-17]. Use of extruded rice bran in the diet of broilers, compared with raw and roasted rice bran, significantly increased fat digestibility which was attributed to lipase and trypsin inhibitor inactivation $[1,15]$. In addition, use of 10, 20 and $30 \%$ extruded rice bran in broiler diets, compared with raw and roasted rice bran, increased weight gain and feed consumption [6]. Sayre et al. [18] showed that feeding $600 \mathrm{~g}$ extruded rice bran $/ \mathrm{kg}$ feed compared with raw rice bran, improved broiler weight gain and feed efficiency during the first two weeks of production, but after the second week, the performance of chicks fed the extruded rice bran was depressed.

The poultry responses to extrusion processing of rice bran are not conclusive, especially $\mathrm{P}$ availability, and more research is warranted to elucidate the dietary effect of extruded rice bran on performance and $\mathrm{P}$ availability in broiler chicks. Therefore, the present experiment was conducted to determine the effect of extruded rice bran on performance and $\mathrm{P}$ availability in broiler chicks.

\section{Methods}

\section{Preparation of rice bran and extrusion process}

Rice bran, provided within $12 \mathrm{~h}$ of milling, was extruded at $125{ }^{\circ} \mathrm{C}$ and 40 -bar pressure by using a high-capacity single-helix extruder (Andritz Extruder, Model EX620, Denmark). The length and diameter of the transport screws were 1600.0 and $210.0 \mathrm{~mm}$, respectively, having a length/diameter ratio of 7.62. The passage time was $10 \mathrm{~s}$. The extruder barrel temperature and the screw speed were controlled by a computer connected to the extruder. Production capacity of the extruder was 2-9 TPH.

\section{Experimental birds and diets}

The study protocol was approved by the Animal Ethics Committee of Shiraz University and the birds were managed in compliance with the Shiraz University animal care guidelines and policies. Two-hundred seven-day-old broilers (Cobb 500), allotted to five dietary treatments with five replicates per treatment and 8 chicks per replicate, and reared in floor pens $(100 \mathrm{~cm} \times 100 \mathrm{~cm})$. Diets consisted of a control diet based on corn and soybean (T1), and diets containing 20 or $30 \%$ rice bran (T2 and T3, respectively) and 20 or $30 \%$ extruded rice bran (T4 and T5, respectively). The diets, formulated according to the recommendations of the National Research Council [19], were fed as starter (8 to $21 \mathrm{~d}$ of age) and grower (22 to $42 \mathrm{~d}$ of age) diets. Ingredients and nutrient composition of the diets are shown in Table 1. All diets were identical in terms of density of metabolizable energy (ME), crude protein, calcium, available $\mathrm{P}$, lysine, methionine and methionine + cystine. In the first week, a balanced cornsoybean diet was fed. The chicks had ad libitum access to feed and water.

\section{Performance and excreta collection}

Data on weekly feed intake, body weight gain, and feed conversion ratio were collected during the starter and grower periods. At 21 day of age, excreta samples, separated from feathers and scales, were collected on aluminum foil for a 24-h period, and then immediately frozen at $-20{ }^{\circ} \mathrm{C}$ until future analysis. The excreta in each group were homogenized, oven-dried $\left(60^{\circ} \mathrm{C}\right.$ for $\left.72 \mathrm{~h}\right)$, and ground with a hammer mill (1-mm screen).

\section{Analytical measurements}

Acid-insoluble ash as an indigestible natural marker in the diet and feces was measured using the procedure proposed by Van Keulen and Young [20]. Total P content was determined spectrophotometrically [21], and total available P was calculated as described by Scott and Balnave [22]. At the end of the experiment (42 d), the left tibia of one bird per replicate was removed and pooled for determination of tibial ash. Briefly, the tibia was separated and cleaned of meat and soft tissues; a longitudinal cut was made in tibia which was then immersed in ethyl ether for $48 \mathrm{~h}$ to remove excess fat. Ashing was performed at $550{ }^{\circ} \mathrm{C}$ for $7 \mathrm{~h}$.

\section{Statistical analysis}

The data were analyzed as a completely randomized design using the GLM procedure of $\mathrm{SAS}^{\circ}$ software [23]. Mean separation was performed using the Duncan's multiple range test at $5 \%$ significant level. Independent comparisons were performed to compare the treatment groups.

\section{Results}

Table 2 shows the broiler performance in terms of feed intake, body weight gain, and feed efficiency. During the starter period, feed consumption of birds receiving T1, T4 and $\mathrm{T} 5$ diets was significantly higher than those receiving T2 and T3 diets. However, non-significant changes in feed intake were found during the grower (22-42 d) $(p=0.5146)$ and overall $(8-42)$ periods $(p=0.2484)$. Birds feeding on the diets containing un-extruded rice bran had a significantly lower body weight gain compared to those on the control diet (T1), T4 and T5 diets. Feed conversion ratio followed the same trend as body weight gain; birds on T1, $\mathrm{T} 4$ and $\mathrm{T} 5$ diets had a lower feed-to-gain ratio $(p<0.05)$.

The effects of dietary treatments on $\mathrm{P}$ availability, weight and ash content of tibia, and internal organ weights are presented in Table 3. Relative to other groups, total $\mathrm{P}$ availability was higher in the control and T4 groups (Table 3). The P availability was 23.6 and 
Table 1 Composition ( $\mathrm{g} / \mathrm{kg}$, as fed basis) of the experimental diets ${ }^{\mathrm{a}}$

\begin{tabular}{|c|c|c|c|c|c|c|c|c|c|c|}
\hline \multirow[t]{2}{*}{ Ingredients and composition } & \multicolumn{5}{|c|}{$\underline{\text { Starter }}$} & \multicolumn{5}{|c|}{ Finisher } \\
\hline & $\mathrm{T} 1$ & T2 & T3 & T4 & T5 & $\mathrm{T} 1$ & $\mathrm{~T} 2$ & T3 & $\mathrm{T} 4$ & T5 \\
\hline Corn & 592.1 & 407.6 & 315.2 & 407.6 & 315.2 & 648.4 & 463.8 & 371.5 & 463.8 & 371.5 \\
\hline Soybean meal, (480 g crude protein/kg) & 357.3 & 334.5 & 323.0 & 334.5 & 323 & 300.1 & 277.1 & 265.7 & 277.1 & 265.7 \\
\hline Raw rice bran & 0 & 200 & 300 & 0 & 0 & 0 & 200 & 300 & 0 & 0 \\
\hline Extruded rice bran & 0 & 0 & 0 & 200 & 300 & 0 & 0 & 0 & 200 & 300 \\
\hline Soybean oil & 13 & 21.3 & 25.5 & 21.3 & 25.5 & 17.8 & 26.2 & 30.3 & 26.2 & 30.3 \\
\hline Dicalcium phosphate & 14.4 & 13.2 & 12.6 & 13.2 & 12.6 & 13.3 & 12.1 & 11.5 & 12.1 & 11.5 \\
\hline Calcium carbonate & 12.5 & 13.1 & 13.5 & 13.1 & 13.5 & 11.7 & 12.4 & 12.7 & 12.4 & 12.7 \\
\hline Salt & 4.2 & 3.9 & 3.8 & 3.9 & 3.8 & 3.1 & 2.9 & 2.8 & 2.9 & 2.8 \\
\hline Vitamin premix ${ }^{\mathrm{b}}$ & 2.5 & 2.5 & 2.5 & 2.5 & 2.5 & 2.5 & 2.5 & 2.5 & 2.5 & 2.5 \\
\hline Mineral premix ${ }^{c}$ & 2.5 & 2.5 & 2.5 & 2.5 & 2.5 & 2.5 & 2.5 & 2.5 & 2.5 & 2.5 \\
\hline DL-methionine (990 g methionine/kg) & 1.5 & 1.4 & 1.4 & 1.4 & 1.4 & 0.6 & 0.5 & 0.5 & 0.5 & 0.5 \\
\hline \multicolumn{11}{|l|}{ Calculated nutrients $^{d}$} \\
\hline Crude protein & 208 & 208 & 208 & 208 & 208 & 188 & 188 & 188 & 188 & 188 \\
\hline $\mathrm{ME}, \mathrm{kcal} / \mathrm{kg}$ & 2900 & 2900 & 2900 & 2900 & 2900 & 3000 & 3000 & 3000 & 3000 & 3000 \\
\hline Lys & 11.2 & 11.2 & 11.2 & 11.2 & 11.2 & 9.8 & 9.8 & 9.9 & 9.8 & 9.9 \\
\hline Met & 4.8 & 4.7 & 4.7 & 4.7 & 4.7 & 3.6 & 3.6 & 3.6 & 3.6 & 3.6 \\
\hline Met + Cys & 8.2 & 8.2 & 8.2 & 8.2 & 8.2 & 6.8 & 6.8 & 6.8 & 6.8 & 6.8 \\
\hline Calcium & 9.1 & 9.1 & 9.1 & 9.1 & 9.1 & 8.4 & 8.4 & 8.4 & 8.4 & 8.4 \\
\hline Total P & 6.7 & 8.8 & 9.8 & 8.8 & 9.8 & 6.3 & 8.4 & 9.4 & 8.4 & 9.4 \\
\hline Available P & 4.1 & 4.1 & 4.1 & 4.1 & 4.1 & 3.8 & 3.8 & 3.8 & 3.8 & 3.8 \\
\hline Sodium & 1.8 & 1.8 & 1.8 & 1.8 & 1.8 & 1.4 & 1.4 & 1.4 & 1.4 & 1.4 \\
\hline
\end{tabular}

${ }^{\mathrm{a} S t a r t e r}(8-21 \mathrm{~d})$; finisher (22-42 d)

T1 control, T2 $20 \%$ raw rice bran, T3 $30 \%$ raw rice bran, T4 $20 \%$ extruded rice bran, T5 $30 \%$ extruded rice bran

${ }^{b}$ Vitamin concentrations per kg of diet: vitamin A $10000 \mathrm{IU}$, vitamin $\mathrm{D}_{3} 2000 \mathrm{ICU}$, vitamin E $10 \mathrm{IU}$, vitamin $\mathrm{K}_{3} 2.5 \mathrm{mg}$, thiamin $1.5 \mathrm{mg}$, riboflavin 5 mg, niacin 40

$\mathrm{mg}$, pantothenic acid $10 \mathrm{mg}$, pyridoxine $5 \mathrm{mg}$, folic acid $1 \mathrm{mg}$, vitamin $\mathrm{B}_{12} 0.01 \mathrm{mg}$, biotin $0.15 \mathrm{mg}$, choline chloride $1200 \mathrm{mg}$

${ }^{c}$ Mineral concentrations per kg of diet: Mn $60 \mathrm{mg}$, Zn $40 \mathrm{mg}$, Fe $80 \mathrm{mg}$, Cu 8 mg, Se $0.15 \mathrm{mg}$

d Based on ingredient composition in NRC (1994)

Table 2 Effect of extruded rice bran on feed intake, weight gain, and feed conversion ratio (FCR) in broiler chicks

\begin{tabular}{|c|c|c|c|c|c|c|c|}
\hline \multirow[t]{2}{*}{ Performance } & \multicolumn{5}{|l|}{ Diets } & \multicolumn{2}{|c|}{ Statistics } \\
\hline & $\mathrm{T} 1$ & $\mathrm{~T} 2$ & T3 & T4 & T5 & SEM & $p$-value \\
\hline \multicolumn{8}{|c|}{ Feed intake (g) } \\
\hline Day 8-21 & $633.1^{\mathrm{a}}$ & $541.0^{\mathrm{b}}$ & $537.3^{b}$ & $622.7^{\mathrm{a}}$ & $605.7^{\mathrm{a}}$ & 42.70 & 0.0031 \\
\hline Day 22-42 & 2483.1 & 2409.8 & 2425.8 & 2429.2 & 2418.7 & 107.74 & 0.5146 \\
\hline Day 8-42 & 3116.2 & 2950.8 & 2963.2 & 3052.0 & 3024.7 & 138.36 & 0.2484 \\
\hline \multicolumn{8}{|c|}{ Body weight gain (g) } \\
\hline Day 8-21 & $504.1^{\mathrm{a}}$ & $411.2^{b}$ & $402.0^{\mathrm{b}}$ & $490.6^{a}$ & $477.1^{a}$ & 36.45 & 0.0004 \\
\hline Day 22-42 & $1102.0^{\mathrm{a}}$ & $910.0^{b}$ & $886.2^{b}$ & $1071.5^{\mathrm{a}}$ & $1044.5^{\mathrm{a}}$ & 44.84 & $<0.0001$ \\
\hline Day 8-42 & $1606.1^{\mathrm{a}}$ & $1321.2^{\mathrm{b}}$ & $1288.2^{\mathrm{b}}$ & $1562.1^{\mathrm{a}}$ & $1521.6^{\mathrm{a}}$ & 66.72 & $<0.0001$ \\
\hline \multicolumn{8}{|l|}{ FCR } \\
\hline Day 8-21 & $1.26^{\mathrm{b}}$ & $1.32^{\mathrm{a}}$ & $1.34^{\mathrm{a}}$ & $1.27^{\mathrm{b}}$ & $1.27^{\mathrm{b}}$ & 0.033 & 0.0041 \\
\hline Day 22-42 & $2.26^{\mathrm{b}}$ & $2.65^{\mathrm{a}}$ & $2.71^{a}$ & $2.27^{\mathrm{b}}$ & $2.32^{\mathrm{b}}$ & 0.090 & $<0.0001$ \\
\hline Day 8-42 & $1.94^{\mathrm{b}}$ & $2.24^{\mathrm{a}}$ & $2.30^{\mathrm{a}}$ & $1.96^{\mathrm{b}}$ & $1.99^{\mathrm{b}}$ & 0.076 & $<0.0001$ \\
\hline
\end{tabular}

T1 control, T2 $20 \%$ raw rice bran, T3 $30 \%$ raw rice bran, T4 $20 \%$ extruded rice bran, T5 $30 \%$ extruded rice bran

${ }^{\mathrm{a}-\mathrm{b}}$ Means in the same row with different letters differ significantly $(p<0.05)$ 
Table 3 Effect of extruded rice bran on P availability, tibial weight and ash, and organ weights in broiler chicks

\begin{tabular}{|c|c|c|c|c|c|c|c|}
\hline \multirow[b]{2}{*}{ Items } & \multicolumn{5}{|l|}{ Diets } & \multicolumn{2}{|c|}{ Statistics } \\
\hline & $\mathrm{T1}$ & $\mathrm{T} 2$ & T3 & T4 & T5 & SEM & $p$-value \\
\hline P availability (\%) & $48.26^{a}$ & $37.44^{c}$ & $35.06^{c}$ & $46.29^{a}$ & $42.54^{b}$ & 2.812 & $<0.0001$ \\
\hline Tibial weight $\mathrm{e}^{\mathrm{e}}$ & 0.34 & 0.36 & 0.35 & 0.34 & 0.35 & 0.022 & 0.5457 \\
\hline Tibial ash $^{f}$ & $47.83^{a}$ & $43.81^{c}$ & $40.40^{d}$ & $47.85^{a}$ & $45.96^{b}$ & 1.312 & $<0.0001$ \\
\hline \multicolumn{8}{|l|}{ Organs $^{e}$} \\
\hline Heart & $0.51^{c}$ & $0.57^{\mathrm{ab}}$ & $0.58^{\mathrm{a}}$ & $0.50^{c}$ & $0.53^{b c}$ & 0.032 & 0.0034 \\
\hline Liver & 2.20 & 2.29 & 2.34 & 2.25 & 2.21 & 0.111 & 0.2981 \\
\hline Pancreas & $0.22^{c}$ & $0.27^{\mathrm{b}}$ & $0.30^{\mathrm{a}}$ & $0.23^{c}$ & $0.22^{c}$ & 0.011 & $<0.0001$ \\
\hline
\end{tabular}

T1 control, T2 $20 \%$ raw rice bran, T3 $30 \%$ raw rice bran, T4 $20 \%$ extruded rice bran, T5 $30 \%$ extruded rice bran

${ }^{a-d}$ Means in the same row with different letters differ significantly $(p<0.05)$

ePercentage of live body weight

fPercentage of dry bone weight

$32 \%$ higher in chicks fed on T4 diet compared with T2 and T3 diets, respectively. No significant difference was found in tibial weight $(p=0.5457)$. Tibial ash content did not differ significantly between $\mathrm{T} 1$ and $\mathrm{T} 4$ groups, which recorded a higher tibial ash content compared to other treatments. Extrusion pretreatment of rice bran increased the tibial ash content in such a way that it was the highest for $\mathrm{T} 1$ and $\mathrm{T} 4$ diets followed by $\mathrm{T} 5$ and then for those containing raw rice bran (T2 and T3).

The weight of internal organs was similar in birds feeding on T1, T4 and T5 diets (Table 3). The pancreatic weight in T2 and T3 groups was higher than in other groups $(p<0.05)$. Compared to the diets containing raw rice bran, the cardiac and pancreatic weights were decreased in response to extrusion treatment $(p<0.05)$, with the birds receiving $\mathrm{T} 3$ diet having the greatest cardiac weight. The liver weight was not affected by treatments.

\section{Discussion}

Published data on the broiler response to rice bran feeding are inconsistent primarily due to differences in fiber, protein and oil contents, lipid rancidity and other constituents [6, 12]. For example, Mujahid et al. [6] reported a decrease in performance and increases in organ weights of broiler chicks fed on diets containing rice bran. In another study, inclusion of $300 \mathrm{~g} / \mathrm{kg}$ rice bran in broiler diets replacing corn, improved live weight gain, whereas feed conversion efficiency remained unaffected [24]. In line with our current results, Gallinger et al. [25] reported a 3.6 and $8.0 \%$ reduction in weight gains of broiler chicks fed 30 and $40 \%$ rice bran, respectively.

The beneficial effect of extrusion processing of rice bran on the performance of broiler chickens was reported by Mujahid et al. (2004) [6]; among the different processing methods evaluated [extrusion cooking, roasting or pelleting and treatment with antioxidant], extrusion processing resulted in better performances. In agreement with our findings, Sayre et al. (1988) reported that extrusion cooking of rice bran improved the productive performance of broiler chicks in terms of weight gain and feed-to-gain ratio in the first two weeks of feeding, which disappeared as the feeding period approached its end [18].

The tibial weight was decreased with the increasing level of rice bran in broiler diet [26]. The phytate form of $\mathrm{P}$ in rice bran was estimated at about $90 \%$ of the total $\mathrm{P}$ with a very low availability; this forms complexes with proteins and starch, which limits calcium, magnesium, iron, and zinc availability [25, 27, 28]. According to Belyea et al. [29], availability of P in rice bran for young turkey poults was only $9 \%$. This limited bioavailability is primarily due to the fact that poultry lack significant amounts of endogenous phytase, the enzyme which is needed for breakdown of phytate-bound $\mathrm{P}$ and subsequent release of $\mathrm{P}$ for absorption [30,31]. Therefore, with regard to the improved utilization of $\mathrm{P}$ in the extrusion-treated rice bran, it might be suggested that extrusion treatment reduced the phytin level, which subsequently makes $\mathrm{P}$ more available to chicks.

Greater P availability may disturb calcium to P ratio, and thus compromise the broiler performance. Therefore, an improvement in dietary calcium to $\mathrm{P}$ ratio with the addition of calcium to the diet containing extruded rice bran is expected to optimize the growth rate in the period beyond two weeks [18].

Mujahid et al. [6] reported that extrusion treatment of rice bran led to a decrease in the pancreatic weight of broiler chicks, but as the level of inclusion increased, the weight of pancreas also increased [6]. Contrary to our findings, Sayre et al. [18] reported no change in the weight of pancreas by extrusion cooking of rice bran. However, the pancreatic weight of birds fed on the control diet (without rice bran) was significantly lower than in birds fed on either raw or extruded rice bran diets. Trypsin inhibitors cause an excessive stimulation of the pancreatic activity and an increase in size and numbers of pancreatic cells [32]. The lower relative weight of 
pancreas in diets containing extruded rice bran might probably be due to destruction of trypsin inhibitors as a result of extrusion treatment, thus demonstrating the effectiveness of extrusion treatment in denaturing the trypsin inhibitor.

\section{Conclusions}

Results of the present study confirmed the potential of extrusion treatment as an efficient processing technology in increasing the quality of rice bran for poultry nutrition. Extruded rice bran up to $30 \%$ of the diet improved the broiler performance and $\mathrm{P}$ availability in broiler chicks.

\section{Competing interests}

The authors declare that they have no competing interests.

\section{Authors' contributions}

AAZS conducted the feeding trial, ran the laboratory analyses and was responsible for the first draft of the manuscript. MA supervised the study and cooperated with the first draft of the manuscript. MJZ coordinated the overall study, analyzed the data and edited the manuscript. MRR cooperated with the study design and writing the draft of the manuscript. MD contributed to manuscript draft and data analysis. FA contributed to the laboratory analyses, preparation of the first draft of the manuscript, and in feeding trial. All authors approved the final manuscript.

\section{Acknowledgment}

Authors would like to thank the staff of the Animal Science Department and Animal Research Station for help during the conduct of the experiment.

\section{Author details}

'Present Address: Golpooneh Safahan Co., Isfahan Science \& Technology Town, Sheikh Bahai Building, Isfahan, Iran. ${ }^{2}$ Department of Animal Science, College of Agriculture, Shiraz University, 71441-65186 Shiraz, Iran.

Received: 30 March 2015 Accepted: 17 June 2015

Published online: 20 July 2015

\section{References}

1. Mujahid A, Asif M, Haq I, Abdullah M, Gilani AH. Nutrient digestibility of broiler feeds containing different levels of variously processed rice bran stored for different periods. Poult Sci. 2003;82:1438-43.

2. Sharif MK, Butt MS, Anjum FM, Khan SH. Rice bran: A novel functional ingredient. Crit Rev Food Sci Nutr. 2014;54:807-16.

3. Farrell D. Strategies to improve the nutritive value of rice bran in poultry diets. III. The addition of inorganic phosphorus and a phytase to duck diets. Br Poult Sci. 1998;39:601-11.

4. Benedito D, Barber S. Toxic constituents of rice bran. Rev Agroquim Technol Aliment. 1978;18:89-92.

5. Ersin Samli H, Senkoylu N, Akyurek H, Agma A. Using rice bran in laying hen diets. J Cent Eur Agr. 2006;7:135-40.

6. Mujahid A, Ui Hag I, Asif M, Hussain GA. Effect of different levels of rice bran processed by various techniques on performance of broiler chicks. Br Poult Sci. 2004:45:395-9.

7. Eshwaraiah C, Reddy V, Rao PV. Feeding value of raw rice polish, deoiled rice polish and parboiled rice polish for broiler starter chicks. Ind J Poult Sci. 1986;21:114-9.

8. Martin E, Farrell D. Strategies to improve the nutritive value of rice bran in poultry diets. II. Changes in oil digestibility, metabolisable energy and attempts to increase the digestibility of the oil fraction in the diets of chickens and ducklings. Br Poult Sci. 1998;39:555-9.

9. Tsvetanov IM, Duneva N. Study on the substitution of maize with rice bran and incineration fat in mixed foods for broiler chickens. Zhivot Nauki. 1990;27:42-5.

10. Kratzer FH, Earl L. The lack of growth depression in poults and coturnix chicks fed raw rice bran. Poult Sci. 1980;59:1626-30.
11. Lamid M, Puspaningsih NNT, Asmarani O. Potential of phytase enzymes as biocatalysts for improved nutritional value of rice bran for broiler feed. J Appl Environ Biol Sci. 2014;4:377-80

12. Farrell DJ. Utilization of rice bran in diets for domestic fowl and ducklings. World Poult Sci J. 1994;50:115-32

13. Ravindran V, Bryden WL, Kornegay ET. Phytases: occurrence, bioavailability and implications in poultry nutrition. Poult Avian Biol Rev. 1995;6:125-43.

14. Warren B, Farrell D. The nutritive value of full-fat and defatted Australian rice bran. I. Chemical composition. Anim Feed Sci Technol. 1990;27:219-28.

15. Ramezanzadeh FM, Rao RM, Windhauser M, Prinyawiwatkul W, Tulley R, Marshall WE. Prevention of hydrolytic rancidity in rice bran during storage. J Agric Food Chem. 1999;47:3050-2.

16. Cheftel JC. Nutritional effects of extrusion-cooking. Food Chem. 1986;20:263-83.

17. Harper JM, Jansen GR. Production of nutritious precooked foods in developing countries by low-cost extrusion technology. Food Res Int. 1985;1:27-97.

18. Sayre R, Earl L, Kratzer F, Saunders R. Effect of diets containing raw and extrusion-cooked rice bran on growth and efficiency of food utilization of broilers. Br Poult Sci. 1988;29:815-23.

19. NRC. Nutrient Requirements of Poultry. 9th ed. Washington: National Academy Press; 1994.

20. Van Keulen J, Young B. Evaluation of acid-insoluble ash as a natural marker in ruminant digestibility studies. J Anim Sci. 1977;44:282-7.

21. AOAC. (Association of Official Analytical Chemists). Official methods of analysis. 15th ed. Washington: Association of Analytical Chemists; 1990.

22. Scott T, Balnave D. Influence of temperature, dietary energy, nutrient concentration and self-selection feeding on the retention of dietary energy, protein and calcium by sexually-maturing egg-laying pullets. Br Poult Sci. 1991:32:1005-16.

23. SAS. Version 9.1. Guide, STAT User's. Cary: SAS Institute Inc; 2003

24. Tiemoko Y. Effects of using rice polishings in broiler diets. Bull Anim Health Prod Africa. 1992:40:161-5.

25. Cosgrove DJ, Irving G. Inositol phosphates: Their chemistry, biochemistry and physiology. Vol. 4. Amsterdam: Elsevier Science \& Technology; 1980.

26. Gallinger Cl, Suárez DM, Irazusta A. Effects of rice bran inclusion on performance and bone mineralization in broiler chicks. J Appl Poult Res. 2004;13:183-90.

27. Juliano BO. Rice: Chemistry and Technology. 2nd ed. St. Paul: Am. Assoc Cereal Chem. Inc; 1985

28. Barber S, Benedito-de BC. Rice bran: chemistry and technology. In: Luh DS, editor. Rice: Production and Utilization. Westport: AVI Publishing Co; 1980.

29. Belyea J, Ledoux D, Garcia A. Bioavailability of phosphorus in stabilized and raw rice bran. J Appl Poultry Res. 1992;1:315-20.

30. Cooper JR, Gowing HS. Mammalian small intestinal phytase (EC 3.1.3.8). Br J Nutr. 1983;50:673-8.

31. Waldroup P, Kersey J, Saleh E, Fritts C, Yan F, Stilborn H, et al. Nonphytate phosphorus requirement and phosphorus excretion of broiler chicks fed diets composed of normal or high available phosphate corn with and without microbial phytase. Poult Sci. 2000;79:1451-9.

32. Leeson S, Summers JD. Scott's Nutrition of the Chicken. Ontario: University books; 2005

\section{Submit your next manuscript to BioMed Central and take full advantage of:}

- Convenient online submission

- Thorough peer review

- No space constraints or color figure charges

- Immediate publication on acceptance

- Inclusion in PubMed, CAS, Scopus and Google Scholar

- Research which is freely available for redistribution 